\title{
"Scientificity" of Social Research: Its Challenges and Implications
}

\author{
Shahir Akram Hassan \\ Centre For Islamic Development Management Studies (ISDEV) \\ School of Social Sciences \\ Universiti Sains Malaysia, Pulau Pinang \\ E-mail: shahir_isdev@yahoo.com \\ Mohd Shukri Hanapi \\ Centre For Islamic Development Management Studies (ISDEV) \\ School of Social Sciences \\ Universiti Sains Malaysia, Pulau Pinang \\ E-mail: hshukeri@yahoo.com
}

Doi:10.5901/ajis.2013.v2n9p62

\begin{abstract}
This paper intends to investigate into the adequacy, challenges and implications of social research that is based on scientific approach. It originates from two basic questions. Firstly, is scientific criteria of social research adequate to contribute to the construction of an holistic Social Sciences? Secondly, what are the challenges and implications of the "scientificity" of the Social Sciences? In general, the concentration of the mainstream social research has been more on the scientific perspective. Observable facts, proven evidences, empirical and measurable evidences are the main manifestations of this scientific perspective. Such a "scientificity" has been developed through conventional research methodology. The problem is, could social research be an holistic research methodology only by concentrating on the scientific realm? If intangible realm such as spirituality is included, is the conventional research methodology posesses adequate tools of analysis in understanding the intangibles? This paper intends to answer these questions and observe the challenges and implications faced by the scientific perspective. For these purposes, a textual analysis will be adopted. It will be shown that scientificity of social research is not a sufficient way to understand an holistic Social Sciences. It is based on some of the challenges such as for instance the question of how to observe the unseen, and quantifying the unquantifiable. From the challenges, it will cause certain implications that will be discussed in this paper.
\end{abstract}

Keywords: Social Research, Scientific, Research Methodology, Qualitative Methods,

\section{Introduction}

During the medieval era, Europe was engulfed with the backwardness of knowledge or better known as the European Dark Ages (Abu Bakar Kasim, 1993:15). The rise of the knowledge era (Renaissance) in the Western world began in Italy in the 14th centuries and later spread to the rest of Eastern Europe. This era was followed by the political revolution, the scientific revolution and the industrial revolution in the West in the next centuries. During the scientific revolution of the 17th century, the flow of Western knowledge dualism began to be spearheaded. The concept of this knowledge dualism is that knowledge is divided into the Natural Sciences and the Social Sciences. At the same time, the process of secularization of knowledge from religion was initiated (Abdul Rahman Abdullah, 2010:115-117).

Not only that, the current social studies as practiced today represents a result of the scientific revolution. This has resulted in an immense influence of the Natural Sciences into the Social Sciences. Among such is the scientificity of social research. It is based on this subject matter that this paper is written. This paper has two main purposes. First, to identify whether the scientific criteria in social studies are sufficient or insufficient to contribute to the building of a comprehensive social sciences; and second, to analyze the challenges and implications for the social studies conducted.

In achieving these two objectives, the discussion in this paper are arranged into four parts. Firstly, it discusses the definition of scientificity and the concept of social research, secondly, it discusses the scientificity challenges in social studies; thirdly, it analyzes the implications on the social studies carried out, and fourthly, conclusions. 


\section{Definitions of "Scientificity"}

The term 'scientificity' adopted in this paper is derived from the word 'scientific', while the word 'scientific' is derived from the word 'science'. However, in this discussion, the authors did not expand the scope science with the meaning of knowledge or the application of knowledge related to the material world (Ahmad Mahzan Ayob, 1997:6). The focus of the subject matter here is the intended use of the term 'scientificity' to describe a social research with scientific characteristics. A social research study with scientific characteristics, on the other hand, is actually a result of a scientific method used. In this case, to have an in-depth understanding of the meaning of "scientificity", it should first be understood what is meant as a scientific method.

According to Goldhaber and Nieto (2010:940), the scientific method is a group of techniques to investigate a phenomenon, acquiring new knowledge or the correction and integration of previous knowledge. Adler and Clark (2008:6), in greater detail, states that the scientific method is a way of conducting empirical studies based on specific objectives, logic and the existent of communication between the research community by connecting the research with theoretical studies.

The term scientific as used by Adler and Clark (2008) is similar to the meaning of scientific method as advanced by Mohamad Najib Abdul Ghafar (1999), Othman Mohamed (2001), and Abdul Rahman Abdullah (2010). According to Mohamad Najib Abdul Ghafar (1999:4-19) and Othman Mohamed (2001:6), scientific brings forth the meaning that any activity that results from a systematic verification process. It is done purposively, selectivity, in-depth, and empirically verifiable (measurement, generalization, can be tested and tested again). While according to Abdul Rahman Abdullah (2010:181), on the other hand, scientific is a method based on empirical principles and experimental or studies which are inductive in character.

Besides Goldhaber and Nieto (2010), Adler and Clark (2008), Mohamad Najib Abdul Ghafar (1999), and Abdul Rahman Abdullah (2010), Sutrisno Hadi (1991) had also tried to present a definition to the term scientific method. According to Sutrisno Hadi (1991:136), the scientific method is a systematic observation and recording of a phenomenon under investigation. Actually, the definition presented by Sutrisno Hadi (1991) is just part of the elements that should exist in the scientific method. Weathington, Cunningham and Pittenger (2010:8) has listed five key elements of the scientific method, that is, hypothesize, operationalize, measure, evaluate and replicate/revise/report. To facilitate researches in remembering these five, Weathington, Cunningham and Pittenger (2010:8) summed it up by using the abbreviation HOMER $(\mathrm{H}$ = hypothesize, $\mathrm{O}=$ operationalize, $\mathrm{M}=$ measure, $\mathrm{E}=$ evaluate and $\mathrm{R}=$ replicate/revise/report).

It is evidently clear that the scientific method relies on human's mind logical reasoning and based on reasonable facts according to the perspective of human thoughts. In addition, a principle discovered by science must be tested empirically. Actually this shows that the scientific method is clearly different from other methods such as 'fate', 'trial' and generalization of the experience (Sheffie Mohd Abu Bakar, 1995:13).

Furthermore according to Mohd Sheffie Abu Bakar (1995:13), the scientific method is based on a belief that every phenomenon has certain proofs, that is every effect has a cause. This method is based on the idea that a conclusion can only be accepted when it is supported by a solid evidence. This does not mean that logical aspects and expertise in research cannot be accepted. Expert statements can only be used if other evidence is scarce. However, by relying only on expert statements, a researcher cannot refer to his study as a result of a research unless supported by evidence that is consistent with the researcher's experience on the matter at hand.

Based on the meaning of scientific in this discussion, it can be concluded that the scientificity of a social research is organized, systematic, purposive, prioritizes logical and rational elements, existent of a controlled variable, can be proven empirically (there should be evidence of statements made by data analysis and information collected to prove a hypothesis or theory), objectivity (solid and convincing), parsimony (linked to previous studies), and generalization of findings.

\section{The Concept of Social Research}

In general, social research is defined as a reality study of humans and society (Neuman, 2011:8). In particular it refers to the use of scientific methods to study the way people organize social life and create a network of contacts to enable them to lead the life (Sharifah Zaleha Syed Hassan, et. al. 2001: 10).

Actually, this social research is conducted by sociologist, social scientist, and others to seek answers to questions about the social world (Neuman, 2011:8). According to Blaikie (2009) and Babbie (2013) social researh is the use of controlled enquiry to find, describe, understand, explain, evaluate and change pattern or regularities in social life. Usually social research refers to a few knowledge disciplines in the social sciences such as history, political sciences, economy, 
psychology, anthropology, sociology, laws, linguistic, communication and eductaion (Gerring, 2001:xv; Neuman, 2011:8; Sharifah Zaleha Syed Hasan, et. al., 2001:14). In understanding something as complex as social interactions or human behaviors and cognitions is not easy (Weathington, Cunningham \& Pittenger, 2010). The empirical, scientific approach to understand social research has been put as a condition but is it efficient?

According to Stanley and Sedlack (1992:ix), social research is very important because it provides information that is needed to be known especially in studying the various social sciences disciplines. Things such as theory, research and analyzing the relationship between theory and research need to be understood as each one of them have their respective roles to solve specific parts of the whole research made. In addition, the use of tools and skills through a rigorous and decisive scientific approach in discussing an issue in the philosophy of science is also important in addition to promoting reconciliation in analyzing various variables as compared to dual variable that is less complicated in a social research. In addition, social research is also important to analyze the phenomena of nature as it is an analysis of the everyday life or the subjective experience of daily life (Wysocki, 2004:13).

\section{Challenges of "Scientificity" in Social Research}

In making the effort to make social studies as a scientific study as discussed earlier, most social studies had to face four major challenges which are interrelated that is the aspects of logic, empirical, measure and evaluate, and purposive techniques.

First, the logical aspect. The scientific approach has put limitations that only things which are logical that can make a social study as a scientific study. In other words, things that are not logical at all are not considered to be scientific. Logic here actually has two meanings. First, the inductive logic and the deductive logic. According to Blaikie (2009) and Neuman (2011:69-70), a social study needs to be done either by way of inductive logic or deductive logic. If the social study is inconsistent or does not meet one of these two types of logic, then it is deemed as excluded from the scientific limitations. Second, logic is something that is acceptable to the human mind. According to Weathington, Cunningham and Pittenger (2010), logic means to always remain in matters that are acceptable to the human mind. It is also named as a rational explanation. It is clear that a social study is not regarded as a scientifcic research when it puts forward a proof or argument that is unacceptable by the mind.

As explained in the previous section, social studies is complex in nature. It is irregular and not equal like other beings besides humans (Weathington, Cunningham \& Pittenger, 2010). If the scientific method is to put a man in a fixed inductive or deductive system, then the question is whether would it be possible? According to Blaikie (2009), the use of deductive logic in everyday life is already difficult, more so to put man into only one system of logic. This is aggravated by logic itself that is constantly evolving. It began with deductive logic and then shifted to inductive logic. Since deductive logic has proven to be unable to guarantee the truth, the study was then done based on inductive logic. In reality, inductive logic is also found open to errors. Although many specific cases have been studied before in which generalizations can be made, nonetheless disputes still arose on certain required specific cases before it can be used as an accurate generalization. If logic is a thing that makes sense then it actually makes the scientific research as having anti-progress tendencies. In this regard, it has already been proven a number of things that do not make sense at one time, but has been proven in the present realities. For example, scientific verification of Deoxyribonucleic Acid (DNA). There was a time when the murder crime could not be proven through fingerprints of the murder weapon but now it could in reality be proven through DNA. In addition, the body cells, hair, nails, semen and blood stains that have been laundered by criminals can also be traced through the study of science and technology.

Second, the empirical evidence aspects. Empirical proof means everything must be proven by the senses. In this case, empiricalism is of the opinion that nothing is ever stored in the human mind, unless there is data firstly obtained from the senses (Hume, 2004; M. Eid Al Munir, 2004). However, the senses actually has limited capacity. This is coupled with human who in itself is a complicated subject. The question is, how are people to be interpreted with this limited sensory capability? What about human's characteristics that cannot be perceived by the senses such as the notion of value, spirituality, emotion and religion? In relation to this if viewed from the spirituality aspects is, it is true there have been efforts made to respond to this kind of matter. One of these is the work done by Muhammad Shukri Salleh (2012) to measure the level of religiosity in development. According to Muhammad Shukri Salleh (2012), the level of religiousity in 
development can be measured with five items namely divinistic ${ }^{1}$, dogmatic ${ }^{2}$, holistic integration ${ }^{3}$, transitory ${ }^{4}$, and instrumentalistic ${ }^{5}$. Since Muhammad Shukri Salleh (2012) combined the data from the senses with the source of divine revelation in measuring the level of religiousity in development, thus it is not regarded as scientifically proven because in the scientific method divine revelation is not recognized as a source of empirical evidence.

The fact is, by revelation there are things that do not require observation or empirical evidence. It is sufficient just to do it right as recommended by revelation. For example, one way to recover from an illness in Islam is through the practice of charity 6 (Abu Dawud, 1986). So far, its effects still could not be proven empirically. In fact there is no logical explanation on the correlation between disease, charity and recovery. However as a matter of fact that is the effect from the revealed guidance. Although there is no empirical correlation, but the effect still brings a win-win situation. Patients will get support from the aspects of emotional tranquility and spiritual satisfaction. The donated money will help a member of the community in need. If Allah SWT permits, the patient will recover and his wealth multiply due the blessings. Not only that, but his level of iman (faith) also increases and is stronger. The truth is, this aspect cannot be proven logically and empirically in a social research.

Third, is the measure and evaluate aspects. In scientific studies, every article or thing that is to be examined must be one that can be measured and evaluated. According to Weathington, Cunningham and Pittenger (2010), one of the assumptions in social science research is that a researcher can measure critical variables. Although it is possible that some variables cannot be measured directly, it can still however be measured indirectly. For example, in natural sciences (physics, chemistry and biology) indirect measurements have been used, especially in measuring the effects of gravity. In this case, no explanation is given as to what and how is gravity. In fact, the need to make all data measurable and can be evaluated are some of the challenges in conducting social research because not all data can be measured or numbered. There is no denying that there exists an effort to renumber a data that is difficult to perceive through the Likert Scale (Rehana Masrur \& Masrur Alam Khan, 2007). If on the level of measuring the data can be done using the Likert Scale, however to what extent can the data be assessed by maintaining the proper level as it should be? What about the results of the analysis and implications of what is proposed? Is it compatible with the notion of number, when it did not originate from the numbers?

Similarly, if the social studies rely completely on measurement and evaluation through numbers, it can lead to error assessment and thus will not be able to solve the actual problem. This is especially if the social studies rely on the tangible or material aspects (Suat Yildirim, 2007:114-115). For example, the study of the behavior of Muslim consumers in buying alcohol. If this study only focused on material point, then the result is likely to find Muslims do not have enough money to buy alcohol; does not have access to alcohol distribution; expensive wine prices as high tax and so on. However, it should be noted that the issue here is the ban on alcohol in Islam. It is in religious adherence. Such examples and possibilities will occur if the social studies is too rigid in its scientific measurement and evaluation.

Fourth, the purposive techniqus aspects. When questions arise about the measurement and evaluation, then there arises the question on the techniques used. Is it enough to understand human? For example, if happy is used as a study, the results certainly show the things that makes a person happy is diversed. In this case, happy in itself is very abstract and subjective, in fact it is not visible.

\footnotetext{
${ }^{1}$ Divinistic here refers to the acquiescence to and the inclusion of the Creator, the God, the One and the absolute in one's dealings (Muhammad Syukri Salleh, 2012).

${ }^{2}$ Dogmatic here refers to the acquiescent acceptance to a set of dogmas embedded in one's belief system, particularly in religion (Muhammad Syukri Salleh, 2012).

${ }^{3}$ Holistic integration here refers to the amalgamation of three all-embracing aspects of one's relationship, viz. the vertical God-man relationship (hablum-minallah), the inward man-inner-self relationship, and the horizontal man-man-nature relationship (hablumminannas) (Muhammad Syukri Salleh, 2012).

${ }^{4}$ Transitory here refers to one's journey of life, living in this world as a temporary stop-over before embarking on the eternal world, the Hereafter (Muhammad Syukri Salleh, 2012).

${ }^{5}$ Instrumentalistic here refers to the usage of all one's actions as tools of worship, undertaking man's function as servants ('abd) and Vicegerent (khalifah) of God (Muhammad Syukri Salleh, 2012).

${ }^{6}$ This is as transmitted by Hassan Al-Basri which brings the meaning: "Treat your sick one by giving sadaqah (charity)", (Hadis Riwayat Abu Dawud: Hadis No 105).
} 


\section{Its Implications}

Based on the discussion about the challenges of scientificity in previous social studies, it is evident that the nature of a social scientific study has some implications. However, in this discussion, the author does not intend to discuss them all. Only three main implications will be discussed here.

First, the scientific method in actual fact does not have sufficient tools to understand human beings as the main objects in social studies. According to the scientific method, some elements such as logic and empiricality cannot provide adequate tools to assess and understand man because it does not take into account aspects which cannot be seen and are illogical. The scientific method seems to narrow the scope of social studies, thus preventing it from understanding the social reality. According to Muhammad Shukri Salleh (2008), scientific studies can only collect information from observations, data and analyze the cause-and-effect of the interaction of these variables. It is as though looking at things from the angle of what is apparent or tangible only. For the avoidance of viewing the scientific method as only from the purely corporeal aspects, thus Northbourne (2008) says there are attempts to interprete psychology and religion according to science. However, such efforts is akin to the 'semi-religious'effort, which puts God in a remote corner of human feelings and emotions.

Second, because the scientific method does not have adequate tools, without realizing, actually the study that follows the scientific method cannot understand human holistically. It makes the social studies to limit the humanity aspects of the research. For example, studies in economics. If a study focuses only on the logical and empirical, the result will show tendencies of the material needs. At the same time, since spiritual aspects cannot be proven scientifically, it then cannot be included. In this case, the community is induced with artifitial needs that cannot help to holistically understand human (Suat Yildirim, 2007:116). Thus, at least most social studies need to balance between the scientific aspects with the humanity aspects.

Third, damage to the 'aqidat (faith with strong interwined conviction). For Muslims, the bigoted attitudes on the scientific methods can actually harm their faith. This is especially so for those who hold to the scientisicm belief. According to Abd Latif Samian (1999:106), the obsession to scienticism can ruin a Muslim's 'aqidat because it leads to 'Intellectual Idolatory'. This occurs as a result of overtly glorifying the findings from science by thinking that scientific discovery is the only real knowledge. As a manifestation of this type of attitude, in most of the industrial nations, a very big honor is given to scientists compared to the honor given to members in other fields such as paleontology and statistics. For example, in the United States a physicist is far more respected than a public medical doctor. Actually the question of bigotry in the scientific method which can harm the 'aqidat is important to understand because one-fifth of the world's population is Muslims. However, this does not mean that the scientific method does not have any good in it but the scientific method should be 'sparingly' used so that the 'aqidat is not affected.

\section{Conclusion}

Scientificity of social research actually has a good purpose. It tries to avoid errors in thinking and researching. However, without realizing it, this has led to the denial of a comprehensive understanding of social reality. As a result, the society is induced with imperfect solution and are less accurate. This demonstrates that in order to understand mankind as a whole (external and internal), it is not enough if the scientific methods alone are applied. It requires an additional tool to get a comprehensive result. Conversely, if the scientific methods remain with the existing judgment, it not only examines people from the external aspects, but will also in all probability lead to damage the 'aqidat of the Muslims ummat (society).

\section{Acknowledgement}

This paper is part of the various output from the research entitled The Art of Reasoning in Islamic Research Methodology and was funded by Research University Individual (RUI) Grant, Universiti Sains Malaysia (2012-2015) [(RUI)1001/PSOSIAL/816207].

\section{References}

Abdul Latif Samian (1999). "Al-Qur'an, Al-Sunnah dalam Falsafah Sains", in Mohd Yusof Othman et. al. (Eds), Siri Wacana Sejarah dan Falsafah Sains, Vol. 7. Kuala Lumpur: Dewan Bahasa dan Pustaka (DBP). 
Abdul Rahman Abdullah (2010). Wacana Falsafah Sains: Sejarah dan Pemikiran. Pulau Pinang: Pusat Kajian Pengurusan Pembangunan Islam, Universiti Sains Malaysia.

Abu Dawud, Sulaiman Bin al-Asy'ath al-Sajistani (1986). Al-Marasil. Beirut: Dar al-Qalam.

Adler, E. S. \& Clark, R. (2008). How It's Done: An Invitation to Social Research. Belmont: Thomson Wadsworth.

Al-Habannakah, Abdul Rahman Hassan (1993). Dowabit al-Ma'rifah. Damsyik: Dar al-Qalam.

Babbie, E. (2013). The Practice of Social Research, 13th ed. United States of America: Wadsworth Cengage Learning.

Bacon, Francis. (1955). Novum Organum Scientiarum. New York: P. F. Collier and Son.

Blaikie, Norman. (2008). Analyzing Quantitative Data. London: Sage Publication Ltd.

Blaikie, Norman. (2009). Designing Social Research. Cambridge: Polity Press.

Gerring, J. (2001). Social Science Methodology: A Critical Framework. United States of America: Cambridge University Press.

Goldhaber, A.S \& Nieto M.M. (2010, January-March). "Photon and Graviton Mass Limits", Review of Modern Physics, 82, p. 939.

Hume, David. (2004). An Enquiry Concerning Human Understanding. United States of America: Barnes and Noble Publishing.

Louay Safi (1996). The Foundation of Knowledge-A Comparative Study in Islamic and Methods of Inquiry. Kuala Lumpur: International Islamic University Malaysia Press.

M. Ied Al Munir (December, 2004). "Tinjauan Terhadap Metode Empirisme dan Rationalisme”, Jurnal Filsafat, 38(3), p. 234-245.

Mat Rofa Ismail (2006). Falsafah Sains: Pendekatan Kualitatif. Kuala Lumpur: Dewan Bahasa dan Pustaka (DBP).

Mills, J.S. (1850). A System of Logic. New York: Harper \& Brothers Publishers.

Mohamad Najib Abdul Ghafar (1999). Penyelidikan Pendidikan. Skudai, Johor: Penerbit Universiti Teknologi Malaysia.

Mohd Sheffie Abu Bakar (1995). Metodologi Penyelidikan. Kuala Lumpur: Dewan Bahasa dan Pustaka (DBP)

Muhammad Syukri Salleh (2008). "Kaedah Penyelidikan Berteraskan Islam: Keperluan, Kedudukan dan Hala Tuju". Pemikir, No. 54, October-December, p. 133-164.

Muhammad Syukri Salleh (2011). "Ke Arah Kaedah Penyelidikan Berteraskan Islam", dlm. Zakaria Bahari, et. al., (Eds.), Pengurusan IImu, Ekonomi dan Pembangunan Berteraskan Islam. Pulau Pinang: Penerbit Universiti Sains Malaysia.

Muhammad Syukri Salleh (2012). "Religousity in Development: A Theoretical Construct of an Islamic-Based Development", International Journal of Humanities and Social Science, 2(14), p. 266-274.

Neuman, W. Lawrence. (2011). Social Research Methods: Qualitative and Quantitative Approaches, 7th ed. Boston: Allyn and Bacon.

Northbourne, Lord. (2008). "Batasan Sains Moden", in Baharuddin Ahmad (Eds), Agama dan Sains Moden. Kuala Lumpur: Dewan Bahasa dan Pustaka (DBP).

Othman Mohamed (2001). Penulisan Tesis Dalam Bidang Sains Sosial Terapan. Selangor: Penerbit Universiti Putra Malaysia.

Rehana Masrur \& Masrur Alam Khan (2007). "Quantifying the Unquantifiable: Developing Quality Measures For Affective Objectives", Masalah Pendidikan, 30(2), p. 19-32.

Sabitha Marican (2005). Kaedah Penyelidikan Sains Sosial. Petaling Jaya: Pearson Malaysia Sdn Bhd.

Stanley \& Sedlack (1992). Social Research: Theory and Methods. Canada: Allyn and Bacon.

Suat Yildirim (2007). "Worldwide Corruption by Scientific Materialism", in Ali Unal (Eds), Islamic Perspectives on Sciences: Knowledge and Responsibility. New Jersey: The Light Inc.

Sutrisno Hadi (1991). Methodology Research II. Yogjakarta: Andi Ofset.

Syarifah Zaleha Syed Hasan, et. al. (2001). Pengantar Sains Sosial. Bangi, Selangor: Pusat Pengajian Jarak Jauh, Universiti Kebangsaan Malaysia (UKM).

Walbridge, J. (2011). God and Logic in Islam: The Caliphate of Reason. Cambridge: Cambridge University Press.

Weathington, Bart L., Cunninghan, Cristopher J. L. \& Pittenger, David J. (2010). Research Methods For The Behavioral And Social Sciences. New Jersey: John Wiley \& Sons.

Wycoski, D. K. (2004). Readings in Social Research Methods. Second Edition. Canada: Wadsworth.

U.S. National Library of Medicine (2013). What is DNA? Accessed on 16 June 2013 from http://ghr.nlm .nih.gov/handbook/basics/dna. 